\title{
Two Library Work-Study Programs in the Boston Area
}

\begin{abstract}
This article examines training programs at the Harvard University library and the Boston public library, where participants simultaneously gain experience at preprofessional positions while studying at a graduate school of library science. The programs' goals and progress are assessed from two points of view (1) the library personnel directors, and (2) the college graduates working in these intern programs. The result of this survey show how other research libraries can establish similar programs for the recruitment of high caliber personnel into librarianship.
\end{abstract}

\section{V}

ARIOUS WORK-STUDY PROGRAMS exist to attract prospective librarians and to help alleviate the shortage of competent preprofessional assistants. The literature on this type of program is comparatively scanty, however, and communication among libraries having such programs seems poor. This article surveys two major, full-time, work-study programs in the Boston area and may be of some introductory use to libraries contemplating the establishment of similar programs for college students studying library science. The plan at the Harvard University library is known as an intern program, and at the Boston public library it is called the Pre-Professional Library Service.

In the first part of this article, the Harvard and Boston public library plans will be analyzed in terms of their history, goals, requirements, and benefits, based on information obtained by interviewing the librarians in charge of each pro-

Mrs. Berkner is Library Assistant in the Center for International Affairs at Harvard University. gram. ${ }^{1}$ To study these programs in action, a five-page questionnaire was sent to each intern, asking about his background, present assignment, responsibilities, and degree of satisfaction with the program. A summary of these questionnaire responses constitutes the second part of this survey.

The Harvard University library intern program was formally begun in January 1961, with five interns; by April 1966, it had expanded to forty-one interns. The program is expected to level off at a maximum of fifty in the next three-tofive years. At present the Harvard library system includes about seven and a half million volumes in ninety-four libraries (mainly in the Boston-Cambridge area) and employs approximately two hundred librarians as well as supporting staff to serve about 25,000 students, faculty, and researchers.

${ }^{1}$ I wish to thank the following persons for their kind assistance and full cooperation, without which this paper could not have been written: H. Gordon Bechanan, Associate University Librarian of the Harvard University Library; Catherine M. MacDonald, Library Personnel Officer, and Edmund R. Ettele, Supervisor of General Library Operations, both of the Boston Public Library; as well as all the interns who responded to the questionnaire sent to them. 
The present preprofessional program at the Boston public library was established in 1938. Data on the early period is not available, but fifty-two persons were employed under the program in 1959 , seventy in 1960 , forty-six in 1964 , and twenty-nine in April 1966. The preprofessionals are employed throughout the BPL system, which includes the huge central research library, twentyseven branches, and three bookmobiles, together containing over two million volumes. The population served is 698,080 , and 172 librarians staff the library system.

The goals and purposes of the Harvard intern program are expressed by $\mathrm{H}$. Gordon Bechanan, associate university librarian, in the letter sent to applicants:

The Program . . . is based primarily on our belief that librarianship is a profession in which the beginner can learn from the practitioner as well as in the classroom. Often, we believe, an individual will derive considerably more from the graduate library curriculum if he has had prior working experience in a library.

Harvard also aims to "work within its own professional machinery," drawing a larger number of young people with language or subject training into academic libraries and educational administration rather than simply staffing the library with specialists recruited from outside the library profession.

The Boston public library feels that the primary goal of its preprofessional program at present ${ }^{2}$ is to fill professional positions with interested people who, although having substandard qualifications in the beginning, will meet the qualifications in the long run. It would be preferable to staff these positions

\footnotetext{
${ }^{2}$ Catherine M. MacDonald and Edmund R. Ettele both suggested that the philosophy of the preprofessional program and its future may change since Philip J. McNiff (formerly head of the Harvard library resources and acquisitions department) has recently become the new director of the BPL.
}

with professionals (even at the higher salary) since professional work would immediately result, but since it is impossible to fill all available openings in that way, the best qualified substitutes must be employed. This may be one explanation for the wide fluctuation in number of preprofessionals employed from year to year. At the same time the BPL hopes to attract people to the library profession by providing a trial period of internship.

To this end the BPL has an active recruitment policy. The library personnel officer regularly gives talks at high schools to introduce the library as a possible career. Two attractive brochures have been prepared to attract college students, and interviews are held on college campuses. The success of this policy is indicated by the lower median age of their beginning interns (BPL men 24, and women 22; Harvard men 26, and women 23 ), and by their having a higher percentage of interns who had no other full-time work, military experience, or graduate training after college (BPL, 35 per cent; Harvard, 15 per cent).

At Harvard, in contrast, recruitment is done passively through the university personnel office (and its career brochure which mentions library positions) and by past and present interns. Without any active recruiting program, Harvard still receives about one hundred twentyfive to one hundred fifty inquiries per year. More than six hundred persons have expressed some interest in entering the program since its inception six years ago, and four hundred forty-five have filed formal applications (as of January 1, 1966), but through April 1966 only one hundred thirty-seven had actually been accepted into the program.

The criteria for selection of participants in the Harvard Intern Program are: (1) acceptance at an accredited library school. This is usually the Simmons graduate school of library science. Lo- 
cated in Boston, this is the only accredited library school in New England. Occasionally, however, interns have preferred to work in the library for about two years and then go to another library school in a different part of the country on a full-time basis; (2) three to five favorable recommendations (personal and academic); (3) academic record of B- or above, except in unusual cases. Ability in at least two foreign languages is generally expected. Previous library experience is not important but certainly recognized. Such skills as familiarity with computer work, or the holding of an advanced degree are welcomed. A personal interview is always required. Here the intangibles of personality and intellect-the most important yet least definable characteristics-are assessed. The potential librarian must have no emotional handicaps, must work well with groups, must be, first of all, "a great human being," "a Renaissance man or woman."

For those applicants who wish some working experience before going to library school or who are not assured of admission to Simmons, an intermediate program has been established at Harvard for "intern candidates." The intern candidate is given the same position as an intern but at a lower salary. He usually changes his status to that of an intern or drops out of the program within six months.

The criteria for selection at the Boston public library more closely follow Simmons' requirements. No one may take a position at the BPL until he has been accepted at Simmons, and then he must begin taking at least one course every semester. An academic record of B- or above and knowledge of one foreign language are required (both prerequisites for admission to Simmons). Recommendations are usually obtained through the applicant's college placement office. A personal interview is required and interest in library work must be shown, but no previous library experience is necessary. The candidate "should have an outgoing personality, and enjoy meeting and working with all types of individuals. A good character, a well groomed appearance, an easy manner, and a willingness to cooperate with others are all essential. ..." 3

The benefits of a preprofessional position at the BPL include the salary beginning at $\$ 4650$ and increasing in increments of $\$ 300$ upon completion of each one-fourth of the library science courses to a maximum of $\$ 5850$. Full tuition ( $c$. $\$ 150$ per course) must be paid out of the salary since no reimbursement is given. Four $\$ 200$ scholarships are awarded annually, however, to preprofessionals who have completed at least one year's service at the BPL. An annual vacation of four weeks (twenty days) is given. No free time is regularly allotted for classes or study, but flexible scheduling can usually be arranged with the department and/or branch librarian because of the long hours during which the library is open. "Pre-pros" may take up to five years to finish the MLS program, but the BPL has no provision for prospective preprofessionals who do not wish to attend library school immediately.

The tangible benefits of the Harvard program include a salary of $\$ 4500$ for the first year of employment, $\$ 4800$ for the second, and $\$ 5200$ for the third. Since July 1966, interns with a master's degree begin at the $\$ 4800$ level or receive $\$ 5200$ if they have already been working for a year. This salary is comparable to that offered by the BPL because Harvard gives half-tuition reimbursement for each course completed with a grade of B- or above. Besides the annual one month (twenty-two days) vacation, interns are given up to seventy hours each year of free time to

\footnotetext{
3 "Advance Recruiting Information: For Colleges and Universities" (Boston: Boston Public Library, n.d.).
} 
be used when necessary for examinations, writing papers, or taking an occasional daytime course. An intern reserve room has recently been established at Harvard, providing study space and a small collection of basic library science literature.

All interns at Harvard are required to study for the master's degree in library science. This is usually done by taking one or two courses per semester at Simmons and working a regular thirty-five hour week. Nine four-credit courses are required for the MLS from Simmons, and Harvard encourages the interns to finish degree work in less than three years.

The "Boston Public Library Personnel Manual" (1960) provides the following guide to job assignments:

The Pre-Professional Library Service is composed of employees who are in training for professional service and who, under the guidance of professional employees, are performing duties that are considered to be professional in nature but which lack the authority, knowledge, and responsibility accorded to positions in the Professional Library Service.

Positions at the BPL are assigned in all areas of public library work such as reference and research, cataloging, rare books, and audio-visual materials, but most openings are in children's or young adults' work. A choice of jobs is usually available, depending upon the applicant's qualifications and aptitudes.

Harvard offers a similar choice of positions, depending upon existing openings. Interns do administrative, reference, and cataloging work, are employed in the main library (Widener), most of the large graduate schools, and some smaller departmental libraries. The largest single group of interns are catalogers. Since Harvard has its own cataloging and classification schemes, all of its catalogers must be trained, and the interns' lack of experience is no disadvantage. Eventually the administration hopes to be able to raise intern salaries almost to the beginning professional level, since their assignments are often the same as those of beginning professionals.

One perennial problem is the intern dropout rate. "Dropouts" are defined as those who do not continue working at their library long enough to receive the MLS. At Harvard, the intern dropout rate is 45 per cent (61 out of 137) of those admitted up to April 1966, a rate much higher than the library administrators had expected. Harvard's higher rate may reflect the inclusion of intern candidates in the total and the fact that some of the interns are married to Harvard graduate students and often have to move from the area when their husband's studies are completed. Marriage, pregnancy, and full-time attendance at Simmons are three other common reasons for leaving an intern program. In studying the dropouts, Harvard found that the person who has had some experience at work, military service, or graduate school before joining the intern program has a better chance statistically of completing the program.

Although the BPL has not made a count, its dropout rate is estimated at only 20 per cent. Since the BPL has a higher percentage of interns with no post-college employment, an actual count might show that the estimated dropout rate is too low. Balancing this, however, is the fact that fewer BPL interns are married to students or other temporary residents.

There is no obligation on the part of either library to offer an intern a professional position at the end of the intern program, nor is the intern obligated to accept a position in the library after completing his internship. In each case, the offer of a professional assignment depends upon the openings available and the caliber of the new librarian. When the intern is asked to stay, however, his previous experience usually re- 
sults in a higher beginning professional position and salary. Of the thirty-five interns who have received the master's degree while working at Harvard, twenty-four were employed there in professional positions as of January 1, 1966. At the BPL, as of the same date, sixtyfive of the 172 professionals were former preprofessionals. These figures alone demonstrate the success of the intern programs for the participating libraries.

The first part of this survey has shown what the administrators at Harvard and the Boston public library intend their programs to accomplish and the type of person they wish to attract. With the permission of the administrators, the seventy interns at the two participating libraries were given opportunity to express their views through a questionnaire. Forty-nine ( 70 per cent) responded with signed questionnaires. To insure candor the interns were assured that the completed questionnaires would not be shown to the library administrators.

Obviously, these responses are subjective, nonprofessional judgments; their importance lies in the fact that the interns who responded show concern for and interest in their programs, and their opinions may be used to avoid or minimize certain objections which the interns raise. Their opinions are of value in indicating possible causes for dropouts and in furthering word-of-mouth recruitment to the programs.

The median age of the interns at the beginning of their participation in either of these programs is $22 \frac{1}{2}$ for women and 25 for men. Many are unmarried (65 per cent). Many have had either fulltime employment, military service, or graduate training after college (71 per cent) and/or have had some previous library experience (65 per cent). This means that about one-third enter the programs without any library experience. Only 24 per cent of the interns had attended graduate school and even fewer had attained a graduate degree (13 per cent), indicating that the programs have not yet been very successful in attracting trained subject specialists. Harvard, which already has at least five interns with an advanced degree ( 20 per cent of respondents), is trying to attract more by offering them a higher beginning salary.

The response to a question asking what the interns would have done had they not been accepted into an intern program points up the differences in recruitment and acceptance policies. The BPL has been successful in recruiting applicants in colleges before they had decided on another career. Only 30 per cent of the BPL interns would have gone into library work without an internship and (perhaps) without the impetus of active recruitment. On the other hand, Harvard interns seem to have had a greater interest in library work for its own sake since 60 per cent would have accepted a library clerical position or attended library school full-time if they had not received an internship. This high percentage may be related to the fact that Harvard interns are, on the average, somewhat older than the BPL pre-pros and have often already tried a nonlibrary position and decided against it.

Although only the BPL personnel office has an active recruitment policy, over half of all the interns first learned about the intern program through a library or university personnel office (62 per cent at BPL, 50 per cent at Harvard). Next in importance are friends (often other interns attending Simmons with the applicant), who were the first source of information about the program for one-quarter of all the interns. Another 12 per cent of the interns were informed by another librarian, either at their previous place of employment or where they had attended college or graduate school. Thus, as former interns from Harvard spread into other academic libraries, this will be an even more important source of advertising. The sur- 
vey shows that academic, rather than public, librarians are more likely to meet prospective librarians at the crucial time during or right after college when most career decisions are made.

The interns were asked to estimate how much of their time was spent in clerical or in professional duties. These categories were not defined for the interns; the important thing about the question was whether or not the interns felt they had responsible, near-professional positions. The BPL, which aims to assign preprofessionals to completely professional positions, seems to have succeeded fairly well: only 20 per cent of the pre-pros believe that more than half of their work is clerical in nature. Harvard's interns are less inclined to agree with the library administration that their positions are "professional or near-professional in nature," since 44 per cent (12) feel that their jobs are made up of more than half clerical work.

Less than a quarter of the interns at each library specifically use their undergraduate major or field of specialization in their work (Harvard 22 per cent; BPL 22 per cent). This indicates either that the libraries are unable to arrange the best job assignments for the interns or that many people choose librarianship with no relationship to or interest in their former speciality. Of the eleven BPL preprofessionals who use their specialization on the job, five said that it is not essential. Their majors were in liberal arts fields such as English or political science, and their present jobs are generally in public service positions.

Harvard requires interns to have foreign language ability beyond what is necessary for admission to Simmons, but only 40 per cent of the Harvard interns (and 10 per cent of the BPL preprofessionals) find this ability essential in their work. However, many interns at both libraries replied that, although language ability was not essential, it was definitely useful-demonstrating the importance of foreign language knowledge in all types of library work.

Slightly more than half ( 57 per cent) of the interns replied that their library science course work was directly useful in their jobs. This leaves a rather large group which did not find course work directly useful. These are often the people doing much clerical work with less chance therefore to apply their knowledge, or they are respondents who had taken only one or two courses and had not yet seen any correlation with their jobs. The latter often commented on this as a limitation in answering this question. On the other hand, most of the interns ( 82 per cent) felt that the experience gained in their jobs made classwork easier. Two typical comments on the intern program read:

It provides a wealth of experience and outlook unavailable in either a job or fulltime schooling. The knowledge learned in one complements the knowledge (good and bad) learned in the other. It provides a richer educational experience.

Attending Simmons while holding a library position helps me to make my work more creative, innovative and efficient by applying what I have learned.

The three reasons offered in the questionnaire for entering an intern program were (1) financial, (2) desire to gain practical experience, and (3) preference for part-time study. The replies confirmed that these were the major advantages of the program for a student. Many people checked more than one, but only three interns added "other" reasons. These three interns had accepted internships only because specific jobs which they wanted just happened to be internships or were so designated by the administration to make the salary acceptable.

The questionnaire included a long list of possible disadvantages of the intern program. The two chief complaints checked by respondents were that the program extends the time needed to earn 
the degree and that it does not allow enough free time for one's own life and family. These are things which the individual library or library school can do little about; they are endemic to any work-study program. The third major complaint was lack of sufficient study time for homework. Since Harvard does allow seventy hours free time for schoolwork, most of the complaints came from the BPL. Most of the advanced courses at Simmons have had only one section each semester and this was often scheduled during the day. Having this free time gives the intern leeway to take whatever course is most necessary for his progress. So much time is expended on courses, research, and visits to other libraries that the seventy-hour allowance is minimal (sometimes even exceeded by the Harvard interns, who then must make up work time). The request for free study time during working hours was the most frequent added comment on the questionnaire by the interns at the BPL (seven out of twenty-one respondents).

A predictable number of complaints about low salary were voiced by the interns at Harvard ( 28 per cent), but over half of the BPL interns (52 per cent) felt they were underpaid, even though their basic salary is larger than that of the Harvard interns. The complaints stem from the BPL's policy of assigning preprofessionals to professional jobs, for which the interns desire equivalent compensation:

I feel that I am doing high-level professional work (at least on the basis of experience in the position) and am not being recompensed sufficiently.

Permit preprofessionals to fill professional positions and be classified and recompensed as such on the basis of experience, ability, and classwork completed.

The number of interns who feel qualified to earn a higher salary (at the moment of answering the questionnaire) in a nonlibrary position is quite high among the men: all of the male preprofessionals at the BPL and five out of six men at Harvard (a striking illustration of why so few good men enter librarianship). Only two of these Harvard interns complained about low salaries while all of the BPL men did. This may be connected to the fact that half of the Harvard men (three who did not complain about low salary) had decided to go into the library field even without an internship, whereas three-quarters of the BPL men would have taken a position outside the library field. The women seem to be more satisfied-only about one-quarter at each library complained about low salaries. However, 46 per cent of the women at the BPL and 38 per cent at Harvard felt that they were qualified to earn more money in some other field.

The other disadvantages checked by interns were too much clerical work (20 per cent), too much pressure (19 per cent), no choice of library position (16 per cent), necessity for taking some undesired courses to fit one's work schedule (16 per cent), and irregular hours (11 per cent). About an equal percentage of Harvard and BPL pre-pros noted these disadvantages.

About 60 per cent each of the Harvard and BPL interns indicated that they attend library meetings of professional organizations and/or within their own library system. At the BPL many of the preprofessionals (especially those in children's and young adults' work) are branch departmental librarians who meet regularly as a group with a branch libraries coordinator. But the preprofessionals working in the central library of the Boston public library get no opportunity to attend regularly scheduled library meetings with others in their system. If the interns are really in training for professional positions, a much higher percentage at both libraries should attend meetings and conferences with the professional librarians in their library system. Inviting the intern to 
participate in professional meetings within the library is a practical and simple way to raise his interest in his work and his knowledge of general library policy and trends.

Almost all the library interns have contacts with other interns in other departments, in their own department, or as personal friends (usually met at Simmons), but only the BPL prepros meet other interns at library meetings. A large number of Harvard interns have some business contact with interns in other departments because a great deal of interdepartmental telephoning is done, and many of the interns have approximately the same level of responsibility in their various departments. At least five people at Harvard specifically requested more formal contact with one another-some planned program to learn about one another's work and studies. They emphasized the need for an orientation at the beginning of the internship to acquaint newcomers with the library system as a whole as well as with other interns. Some of the specific requests were:

Opportunity for all interns to attend meetings of professionals within Widener with the departmental libraries - to be at least aware of the big trends and problems currently under discussion.

Opportunity to get to know the whole library system and other interns by tours (more than one hour!), visits, meetings.

Contrary to Harvard's practice, the BPL does not set the interns apart as a special, rather privileged group. At the BPL the preprofessionals work with other professionals as professionals. Indicating their acknowledgment of this higher status, no preprofessionals suggested that more contact with one another be planned.

Half of the interns polled would prefer a "rotating internship," that is, assignment to more than one department during the period of internship. Of those who would prefer rotation, however, 76 per cent either intend to work in another area of specialization (as professionals) or have not yet decided on their future specialization. Of those who do not wish to rotate, 61 per cent do intend to specialize in that area in which they are now employed. There are also logical reasons for the minority of respondents who do not fit this pattern. At least three of the six interns who want rotation and are now working in their chosen area of specialization hope to go into or continue in library administration, where familiarity with many areas of library work will be of great value. One intern who did not want a rotating internship commented that the question was relative: he enjoyed his present assignment and was therefore not interested in changing. But if he had found his specific position unsatisfactory, he might have preferred rotation. Many of those who intended to change areas but did not want to rotate indicated that rotation would reduce the amount of responsibility which they had. Nevertheless, there is a clear desire on the part of many interns ( 51 per cent) to have the choice of rotating.

At present, neither library offers its interns the regular opportunity to gain experience in more than one department during his internship. A few interns have held two different positions during their internships, usually because their original assignments were unsatisfactory and they demanded a change. Harvard does offer some variety to approximately four interns every year who are given the opportunity to work with the reference librarian in the main library for half a day on alternate Saturdays (in addition to their regular assignments).

The results of this survey indicate that the majority of interns are basically pleased with the programs. Where criticisms are made, they are constructive, if sometimes idealistic. The interns seem to feel the lack of an over-all administrative plan which would allow less variation in the potential and growth possi- 
bilities of an intern position, which would utilize instead of stifle the intern's initiative, enthusiasm, and creativity. A common request by the interns was that this be a training program rather than a way to get cheap professionals-or overpaid clerks. Departmental supervisors vary in their interpretations of their responsibilities within the intern plans. To avoid this, interns have suggested that supervisors be made aware that the interns are in training to learn both general library principles and their specific application to their library system. Attendance at library meetings and tours and the opportunity to understand the reasons behind administrative deci- sions within their area of work all contribute to the "responsibility with guidance" which interns have requested. Further suggestions included a periodic, written evaluation of the intern's work by his supervisor for the benefit of both the intern and the central administration, plus-if not a chance for rotationat least more opportunity for promotion and transfer. The excellent ideas of these intern programs have captured the imagination of some outstanding prospective professionals. Now the administrators must keep these interns constructively and creatively occupied within the field of librarianship.

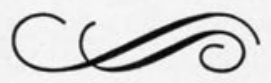

